\title{
Simposio Internacional sobre igualdad en la educación y la comunicación, organizado por el Grupo de Investigación “Género, Estética y Cultura Audiovisual (GECA)" de la Universidad Complutense de Madrid
}

\author{
DAVID PÉREZ SAÑUdo \\ Universidad Complutense de Madrid
}

doi: http://dx.doi.org/10.20318/femeris.2016.3239

El pasado 20, 21 y 22 de abril de 2016 tuvo lugar en la Facultad de Ciencias de la Información de la Universidad Complutense de Madrid el "Simposio Internacional sobre igualdad en la educación y la comunicación: eliminación de los estereotipos sexistas en el diseño de campañas de información, orientación académica y comunicación desde entidades y la comunicación personal", organizado por el Grupo de Investigación validado UCM “Género, Estética y Cultura Audiovisual (GECA)", dirigido por el IP de GECA, el profesor Francisco A. Zurian, gracias a la financiación de un proyecto competitivo del Instituto de la Mujer del Gobierno de España y del Fondo Social Europeo de la Unión Europea.

Se ha planteado un Simposio Internacional sobre los resultados de trabajos y proyectos de investigación distribuidos en:

- 3 ponencias-marco.

- 4 intervenciones oficiales.

- y 16 paneles (cada panel con, usualmente, unos 5 ponentes) con un total de 71 ponentes y 16 moderadoras-es.

Es decir, un total de 94 investigadoras e investigadores de prestigio (que fueron seleccionados por un sistema de revisión ciego por pares miembros del Comité Científico Internacional y que se puede consultar en: https://www.ucm.es/geca/congresos-y-simposios-2016) que han puesto en común el estado de sus investigaciones y han expuesto las principales líneas actuales de investigación y actuación en el ámbito internacional y nacional sobre estudios de mujeres, feminismo y de género y su relación con la educación y la cultura audiovisual, como vehículos de construcción social y cultural para la igualdad de trato y de oportunidades entre mujeres y hombres, organizados en las siguientes áreas:

1. "Género y Educación" (2 paneles)

2. "Violencia de Género" ( 2 paneles)

3. "Publicidad, Género e Igualdad" (2 paneles)

4. “Género, arte, documentación" (1 panel) 
5. "Género y Representaciones televisivas" (1 panel)

6. "Periodismo, Género e Igualdad" (1 panel)

7. "Género y Deporte" (1 panel, con la asistencia de la directora de comunicación del Consejo Superior de Deportes)

8. "Cine, género e igualdad" (3 paneles)

9. "Género y América Latina" (1 panel, incluye inmigración e integración cultural)

10. “Género y el franquismo y la transición” (1 panel)

11. "Estudios LGTBIQ" (1 panel)

12. "Redes Sociales y Género" (1 panel)

(Se pueden cotejar mejor las intervenciones y temáticas en el programa del Simposio que se puede cotejar como adjunto al final de este documento y en la Web oficial de GECA: https://www.ucm.es/geca/congresos-y-simposios-2016).

Hay que destacar la gran presencia nacional e internacional compuesta por, nada menos, que de 39 universidades distintas, distribuidas de la siguiente manera:

- 23 universidades españolas (p.e., todas las madrileñas estuvieron presentes)

- 16 Internacionales, entre ellas:

- 3: Norteamericanas

- 3: Alemanas

- 3: Británicas

- 2: Francesas

- y 5: Latinoamericanas

Todos estos datos son los que hacen tan especiales estos congresos internacionales de GECA que se vienen organizando desde 2010 cada abril y que han ido consiguiendo que los estudios sobre género, feminismo, mujeres, masculinidades, hombres, estudios LGBTIQ en conexión con el área de conocimiento de Comunicación Audiovisual y Publicidad vayan adquiriendo la visibilización que se merecen dentro de nuestro sistema académico.

El nivel de asistencia ha sido muy bueno. El Simposio se ha desarrollado en sesiones plenarias y en sesiones paralelas de hasta 3 salas simultáneas y que ha atraído una media de 200 personas/día, con picos mayores en determinados paneles, como, por ejemplo, el de educación, violencia de género, cine, televisión y deporte que llenaron las salas. Sin contar con la gente que lo siguió por medio de las Redes Sociales:

- Facebook: https://www.facebook.com/GECA.UCM/

- Twiter: https://twitter.com/\#!/GECAudiovisual

- Linkedin: http://es.linkedin.com/in/gecaucm

- Canal YouTube: GECA-TV: www.youtube.com/tvgeca 
Entre el público asistente hemos tenido investigadores y académicxs, doctorandxs pero, también, un muy nutrido porcentaje de trabajadores y voluntarixs de ONGs, Asociaciones, Fundaciones, funcionarixs de ayuntamientos y autonomías encargados de igualdad, asistencia a victimas de maltrato, integración, etc.; también de directoras y funcionarias de diversas unidades de igualdad de diferentes universidades españolas (y 2 latinoamericanas). En este sentido, involucrar a la "Asociación Universitaria Contra La Violencia Machista (AUVIM)", la "Asociación de Mujeres Cineastas y del Audiovisual (CIMA)", la "Fundación Triángulo" y la "FELGTB" ha sido muy efectivo a la hora de conseguir mayor participación social.

En este Simposio Internacional hemos analizado y ofrecido propuestas diversas y hemos elevado al Instituto de la Mujer unas Recomendaciones que el Simposio consideran absolutamente básicas y que el Gobierno debería implementar; dichas recomendaciones son (las copiamos textialmente):

1. Es del todo necesario que se reconozca por el Gobierno de España a los Estudios de Género (y, con ellos, a los Estudios Feministas y de las Mujeres, Estudios sobre Hombres y Masculinidades, Estudios LGTBI y Teoría Queer) como área de conocimiento. Sin este reconociendo la actividad científica sobre Género siempre estará subvalorada, infra-representada en los proyectos de investigación (y en su financiación) y no competirá en igualdad de condiciones con otras áreas y saberes. Esto tiene, además, implicaciones muy importantes (y graves) en las carreras académicas y profesionales (al discriminar en su valoración, por ejemplo, las aportaciones realizadas en ésta área cara, por ejemplo, a las evaluaciones de la ANECA o al competir por conseguir proyectos de financiación, etc.).

2. Se debería contar con una asignatura o parte de ella de una asignatura obligatoria en la enseñanza primaria, secundaria y bachillerato en la que el temario refleje el fundamento de la igualdad de trato, igualdad de género, convivencia y respeto por la identidad (propia y ajena) así y como (y a la vez) que el respeto a la diversidad.

3. Se debería contar de forma trasversal, en todas las asignaturas la enseñanza en igualdad y respeto. Es fundamental combinar una enseñanza específica (gracias a asignaturas concretas) con una enseñanza trasversal para enseñar que estas cuestiones no son un factor sin más sino que es un factor que acompaña y se mezcla en todos y cada uno de los aspectos de nuestra vida, nuestra convivencia y nuestro conocimiento.

4. No se deben permitir centros educativos públicos y concertados donde no exista pluralidad de géneros, culturas, razas y procedencias. Se constata que siguen existiendo centros concertados con discriminación de género y enseñanza única a chicos o a chicas; o centros donde no se admiten emigrantes extranjeros o se hace en un porcentaje tan ínfimo que únicamente pueden ser catalogados como un fraude o donde no se respeta la pluralidad religiosa y se obliga e insta a todo el alumnado a asistir a clases de religión católica, etc. Creemos que la inspección no 
toma las suficientes medidas porque la claridad normativa y la voluntad política son ambiguas. Y esa ambigüedad es, en sí misma, discriminatoria.

5. Existe una carencia enorme de redes de casas de acogida para mujeres víctima de la violencia de género. Se debe hacer una política de casas seguras y con la pertinente dotación de seguridad, asistentes sociales y económica.

6. Se debe ser más vigilante fomentando los Observatorios Nacionales de Igualdad e Integración que ofrezcan datos reales y contrastados y que además puedan realizar una labor de denuncia en los ámbitos de la Publicidad, el periodismo y los medios audiovisuales.

El Grupo de Investigación validado de la Universidad Complutense de Madrid “Género, Estética y Cultura Audiovisual (GECA)" viene funcionando desde 2007 (https://www. ucm.es/geca/geca-presentacion) y, entre sus últimas publicaciones cabe destacar: Construyendo una mirada propia: mujeres directoras en el cine español (de los orígenes al año 2000) y Diseccionando a Adán: representaciones audiovisuales de la masculinidad, ambos libros editados por Síntesis (cfr.: https://www.ucm.es/geca/geca-publicaciones). 